\title{
Penerapan Model Pembelajaran Kooperatif Tipe Teams Games Tournament (TGT) untuk Meningkatkan Hasil Belajar IPS
}

\section{Nyoman Lastia ${ }^{*}$}

${ }^{1}$ SD Negeri 1 Sekumpul, Singaraja, Indonesia

\section{A R T I C L E I N F O}

Article history:

Received 12 October 2020

Received in revised form

10 November 2020

Accepted 10 January 2021

Available online 01

February 2021

Kata Kunci:

Teams Games

Tournament, Hasil Belajar

Keywords:

Teams Games Tournament,

Learning outcome

\begin{abstract}
A B S T R A K
Penelitian ini bertujuan yaitu mengkaji penerapan model pembelajaran Kooperatif Tipe Teams Games Tournament (TGT) untuk meningkatkan hasil belajar. Penelitian ini adalah penelitian tindakan kelas yang melibatkan siswa kelas VI yang berjumlah 16 orang siswa. Obyek penelitian ini adalah hasil belajar IPS. Dalam penelitian ini data hasil belajar siswa dikumpulkan dengan tes hasil belajar, metode analisis data dengan analisis deskriptif. Hasil penelitian ini menunjukan bahwa hasil belajar mata pelajaran IPS melalui penerapan model pembelajaran Kooperatif Tipe Teams Games Tournament (TGT) pada siswa kelas VI dinyatakan meningkat, hal dibuktikan terjadi perbedaan hasil belajar antara siklus I (jumlah 1065, rata-rata 67, daya serap 67, ketuntasan belajar $69 \%$ ) dan siklus II (jumlah 1170 , rata-rata 73 , daya serap $73 \%$, ketuntasan belajar $94 \%$ ). Terjadi peningkatan hasil belajar antara siklus I dan siklus II, menunjukan kenaikan rata-rata daya serap 6\% dan pada ketuntasan belajar mengalami kenaikan sebesar 25\%. Kesimpulan penerapan model pembelajaran Kooperatif Tipe Teams Games Tournament (TGT) pada siswa kelas VI SD dapat meningkatkan hasil belajar IPS.
\end{abstract}

\section{A B S T R A K}

This study aims to examine the application of the Cooperative Learning Model Type Teams Games Tournament (TGT) to improve learning outcomes. This research is a classroom action research involving 16 class VI students. The object of this research is the result of social studies learning. In this study, data on student learning outcomes were collected by means of learning outcomes tests, data analysis methods were descriptive analysis. The results of this study indicate that the learning outcomes of social studies subjects through the application of the Teams Games Tournament (TGT) Type Cooperative learning model in class VI students are stated to have increased, this is evidenced by differences in learning outcomes between cycles I (total 1065, average 67, absorption 67, completeness learning 69\%) and cycle II (total 1170, average 73, 73\% absorption capacity, 94\% learning completeness). There was an increase in learning outcomes between cycle I and cycle II, showing an average increase in absorption of $6 \%$ and learning completeness an increase of $25 \%$. The conclusion is that the application of the Cooperative Learning Model Type Teams Games Tournament (TGT) in grade VI SD students can improve social studies learning outcomes.

\section{Pendahuluan}

Pelajaran IPS adalah salah satu mata pelajaran yang diajarkan di bangku sekolah dasar. Melalui pembelajaran IPS di sekolah, siswa diharapkan memiliki pengetahuan dan wawasan tentang konsep dasar ilmu sosial dan humaniora, memiliki kepekaan dan kesadaran terhadap masalah sosial dilingkungannya, dan mampu memecahkan masalah sosial secara baik, yang pada akhirnya mereka dapat menjadi warga Negara yang baik dan bertanggung jawab(Kristin \& Kencana, 2019; Kurniasari \& Setyaningtyas, 2017). IPS merupakan mata pelajaran sosial yang sangat penting untuk diajarkan, dengan pembelajaran IPS maka

Copyright (c) Universitas Pendidikan Ganesha. All rights reserved 
siswa akan memiliki bekal untuk menghadapi kehidupan sosial dalam masyarakat sekitar (Andari et al., 2019; Kurniasari \& Setyaningtyas, 2017). Proses pembelajaran IPS bertujuan agar siswa memiliki kemampuan mengenal konsep yang berkaitan dengan kehidupan masyarakat dan sosial dapat berfikir logis dan kritis, memiliki rasa keingintahuan dalam memecahkan masalah yang ada di lingkungan sekitar (Horohiung \& Sarkadi, 2016; Suaeb et al., 2018). Dalam mengajar guru hendaknya lebih kreatif dalam memilih metode-metode pembelajaran yang sesuai dengan keadaan serta kondisi lingkungan tempat guru tersebut mengajar. Pemilihan dan penentuan strategi dan metode pembelajaran yang sesuai dengan karakteristik materi yang diajarkan diharapkan akan memudahkan siswa dalam memahami materi tersebut, selain itu siswa bisa lebih berperan aktif dalam proses belajar mengajar. Hasil belajar yang maksimal tentunya didukung oleh aktivitas belajar siswa yang tinggi. Artinya, di dalam kelas guru hanya sebagai mediator/fasilitator, kemudian siswa sebagai subjek sekaligus objek pembelajaran. Siswa hendaknya harus aktif di dalam kelas. Jika siswa aktif, maka kemungkinan besar hasil belajarnya akan meningkat. Namun pembelajaran IPS di SD Negeri 1 Sekumpul masih banyak dilakukan secara konvensional/tradisional (pembelajaran yang berpusat pada guru), serta lemahnya kemampuan guru dalam mendorong dan memotivasi siswa sehingga menjadikan hasil belajar IPS masih rendah bila dibandingkan dengan mata pelajaran lainnya.

Pelajaran IPS selalu disajikan secara verbal melalui kegiatan ceramah dan dengan keterlibatan siswa secara minim karena siswa hanya melakukan kegiatan mendengar, mencatat, dan menghafal, sering siswa merasa bosan dikarenakan pembelajaran kurang menarik. Guru juga jarang menggunakan media sebagai alat bantu penyampaian materi agar siswa paham dengan maksud materi yang disampaikan. Sebagai dampak dari proses pembelajaran yang dikembangkan guru sejalan dengan hasil belajar siswa tidak sesuai dengan harapan guru. Hasil belajar IPS pada tes awal yang dilaksanakan pada tanggal 17 Januari 2019, didapatkan rata-rata hasil belajar IPS sebesar 60, daya serap 60\%, dengan ketuntasan belajar $31 \%$ (5 orang siswa). Sedangkan rata-rata hasil belajar IPS yang ditetapkan dalam kriteria ketuntasan minimal adalah sebesar 70, dengan ketuntasan belajar sebesar $85 \%$. Tercapainya sebuah tujuan dalam pembelajaran itu ditandai oleh adanya hasil belajar siswa yang baik. Oleh karena itu, hasil belajar menjadi salah satu hal yang sangat penting dalam proses pembelajaran. Berkaitan dengan masalah tersebut, ada beberapa faktor yang mengakibatkan hasil belajar siswa rendah. Faktor tersebut adalah pertama metode yang digunakan oleh guru masih konvensional. Artinya guru hanya menggunakan metode ceramah saja. Pada umumnya proses pembelajaran dengan metode ceramah sangat sulit ditinggalkan sehingga kurang melibatkan siswa karena hanya guru yang aktif, sehingga siswa hanya bisa menerima apa yang diberikan oleh gurunya. Memang secara umum metode ceramah tidaklah buruk. Namun, apabila diterapkan secara monoton maka akan menimbulkan kejenuhan dalam diri siswa. Hal ini menyebabkan siswa kurang aktif serta akan mengakibatkan siswa sangat sulit mengembangkan ide-ide dan mengajukan pertanyaan. Semua itu akan berujung pada hasil belajar siswa yang menurun. Faktor lain adalah kurangnya fasilitas belajar siswa. Jika, fasilitas belajar siswa kurang, tentu guru kesulitan untuk menciptakan situasi belajar yang kondusif. Semua itu, akan berimplikasi pada hasil belajar siswa yang rendah. Selain itu, kurangnya kemampuan guru memanfaatkan sarana dan prasarana belajar seperti penggunaan alat-alat elektronik, dan terbatasnya buku-buku penunjang, sehingga mengakibatkan sulit mengkondisikan siswa dalam proses pembelajaran. Ditambah juga lingkungan yang kurang mendukung sehingga minat siswa untuk belajar sangat rendah. Melihat permasalah tersebut di atas, ada ketertarikan peneliti untuk mencari cara untuk memecahkan masalah. Ide peneliti dalam memecahkan masalah tersebut adalah dengan menerapkan model pembelajaran kooperatif tipe Teams Games Tournament (TGT).

Model pembelajaran kooperatif tipe TGT sesungguhnya adalah model pembelajaran yang menyajikan suatu konsep dengan disertai belajar secara kelompok dan permainan, serta berhubungan dengan bagaimana seseorang belajar atau gaya atau cara siswa belajar, relevansi dan manfaat penuh terhadap belajar. Model pembelajaran TGT ini sangat cocok untuk diterapkan karena tahap siswa SD dimana siswa masih suka dengan dunia bermain (Listyarini et al., 2018). TGT dapat meningkatkan pemahaman konsep siswa (Laila \& Rahmat, 2018). Model pembelajaran ini dapat meningkatkan kinerja pengajaran guru dan prestasi belajar siswa, serta merupakan suatu kiat, petunjuk, strategi, dan seluruh proses belajar yang dapat mempertajam pemahaman daya ingat, serta belajar sebagai proses yang menyenangkan dan bermakna (Susanna, 2018). TGT salah satu tipe atau model pembelajaran kooperatif yang mudah diterapkan, melibatkan aktivitas seluruh siswa tanpa harus ada perbedaan status, melibatkan peran siswa sebagai tutor sebaya dan mengandung unsur permainan dan penguatan (AP \& Amir, 2018; Rosdiani et al., 2013; Teladaningsih et al., 2019). TGT diharapkan mampu membuat peserta didik lebih semangat belajar dan tidak merasa bosan, karena model pembelajaran TGT memuat adanya game/turnamen di dalam kelas yang dimana pemenang turnamen ini akan diberikan suatu penghargaan, maka peserta didik akan terpacu untuk menjadi yang terbaik (Hikmah et al., 2018). Pembelajaran TGT di 
kelas, menuntut siswa aktif dalam pembelajaran baik secara fisik, mental maupun emosional guna mencapai hasil belajar yang optimal(Astuti1 \& Kristin, 2017). Jadi, adanya model pembelajaran TGT akan meningkatkan hasil belajar siswa, karena proses pembelajaran yang dilakukan sesaui dengan karakteritik anak SD.

Memperhatikan hal tersebut maka dirumuskan tujuan penelitian yaitu mengkaji penerapan model pembelajaran Kooperatif Tipe Teams Games Tournament (TGT) untuk meningkatkan hasil belajar IPS pada siswa kelas VI SD Negeri 1 Sekumpul semester II tahun pelajaran 2018/2019". Dengan harapan siswa lebih mudah memahami materi yang disampaikan oleh guru dan mampu mengkonstruksikan materi tersebut. Manfaat yang diharapkan dalam penelitian ini bagi siswa. Dapat memberikan pengalaman belajar, karena dilibatkan secara langsung, maka siswa dapat bertukar pendapat atau pikiran dalam proses pembelajaran, bagi guru adalah memiliki pengetahuan untuk menerapkan model pembelajaran kooperatif TGT untuk diterapkan pada mata pelajaran yang lainnya.

\section{Metode}

Penelitian tindakan kelas ini dilaksanakan di SD Negeri 1 Sekumpul dengan alamat Banjar Dinas Desa, Desa Sekumpul Kecamatan Sawan Kabupaten Buleleng. Penelitian ini dilaksanakan di kelas VI SD Negeri 1 Sekumpul pada semester II tahun pelajaran 2018/2019 selama 4 bulan dari Januari sampai dengan bulan April 2019 dengan jumlah siswa sebanyak 16 orang, terdiri dari 9 orang laki-laki dan 7 orang perempuan. Rancangan penelitian ini menggunakan jenis rancangan Penelitian Tindakan Kelas (PTK). Penelitian Tindakan Kelas (PTK) bertujuan untuk memperbaiki kegiatan pembelajaran agar dapat menciptakan hasil belajar yang optimal. Penelitian ini merupakan jenis penelitian tindakan kelas yang pelaksanaannya dirancang dalam dua siklus. Arikunto (2006:92 dalam Sukejani. 2015: 43) menguraikan bahwa: "tiap siklus terdiri dari empat tahapan (1) perencanaan tindakan, (2) pelaksanaan tindakan), (3) pengamatan dan evaluasi serta (4) refleksi tindakan". Sebagai gambaran yang jelas tentang rancangan penelitian tindakan kelas dapat dilihat pada Gambar 01.

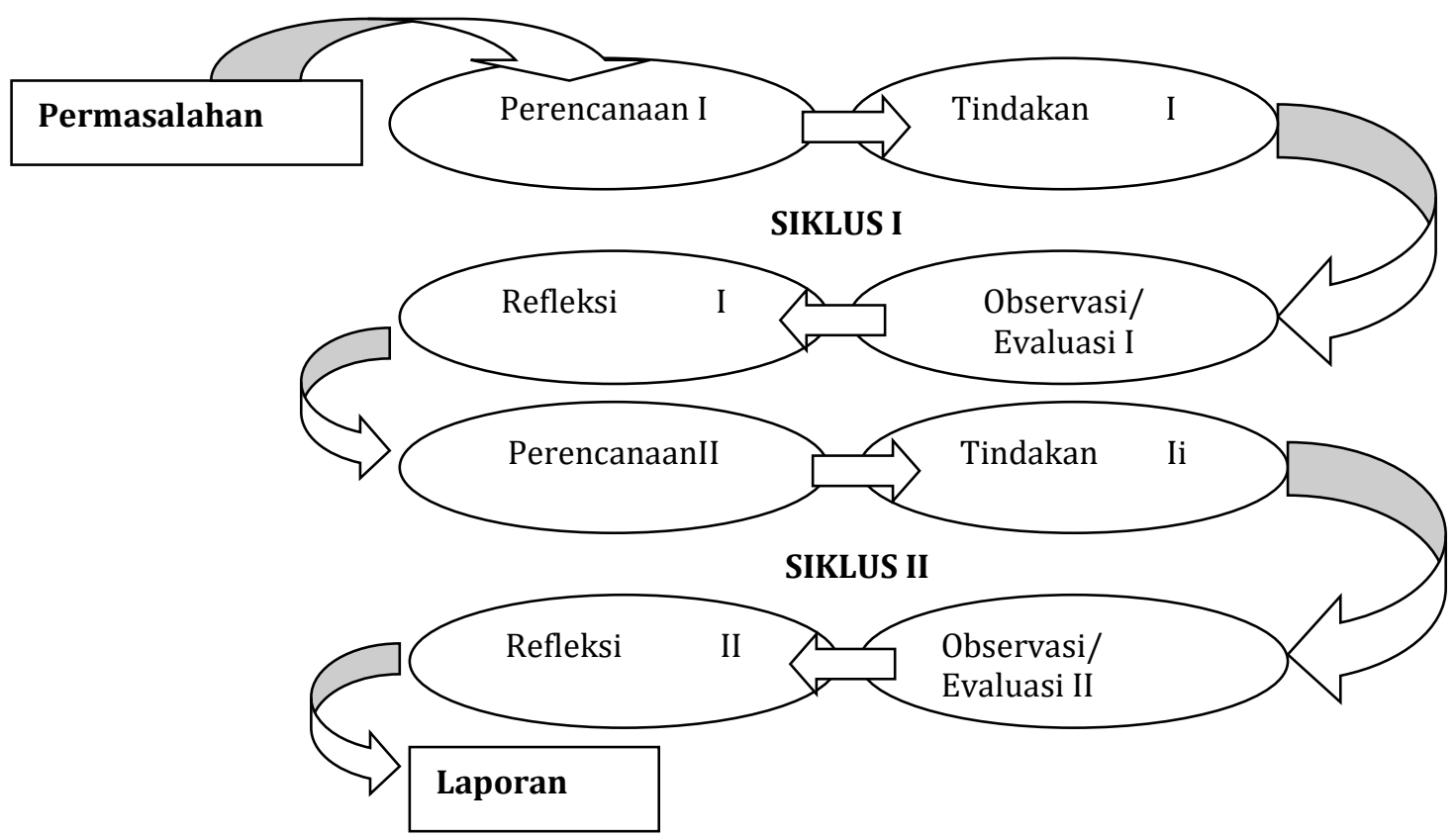

Gambar 1. Bagan Siklus Penelitian Tindakan Kelas (Suyanto, dkk., 1997: 21 dalam Parna. 2015: 15)

Penelitian tindakan kelas ini dilaksanakan sesuai dengan rancangan penelitian seperti pada gambar di atas. Penelitian ini dimulai dengan siklus I dimulai dengan perencanaan seperti: (1) menentukan materi ajar dan (2) menyiapkan instrumen penelitian berupa rencana pelaksanaan pembelajaran (RPP) yang sesuai dengan sintaks model pembelajaran kooperatif tipe TGT dan tes hasil belajar IPS. Pada tahap pelaksanaan, peneliti melaksanakan semua perencanaan pembelajaran yang telah disusun. Secara garis besar pelaksanaan proses pembelajaran adalah: (1) menyampaikan tujuan pembelajaran ke siswa yang akan dilaksanakan, (2) menjelaskan materi tentang cara-cara menghadapi 
bencana alam, (3) melakukan tanya jawab terhadap materi pelajaran, (4) membagi siswa menjadi beberapa kelompok belajar yang terdiri dari 5-6 orang siswa yang heterogen (pengelompokan disesuaikan dengan jumlah siswa, (5) siswa diberi tugas untuk menjawab soal-soal dalam bentuk LKS bersama kelompoknya, (6) membimbing siswa dalam kelompok, (7) memberikan nilai LKS yang telah dikerjakan oleh setiap kelompok, (8) mengadakan Tournamen dilakukan dengan membuat meja-meja turnamen yang terdiri dari 5-6 orang wakil setiap kelompok dengan kemampuan yang sama, yang bertujuan untuk memastikan bahwa seluruh anggota kelompok telah menguasai pelajaran, (9) dalam tournamen siswa menjawab soal-soal yang telah dipilih dalam kartu bernomor, (10) skor yang diperoleh setiap siswa dalam turnamen ini dicatat pada lembar penilaian, (11) menghitung skor tim berdasarkan turnamen anggota dari tim, (12) merekognisikan setiap tim apabila mereka berhasil melampaui kriteria yang telah di tetapkan sebelumnya, (13) memberikan penguatan terhadap hasil tournament yang dilakukan oleh siswa, (14) memberikan penghargaan kepada semua kelompok sesuai skor yang diperoleh.

Observasi dilakukan setiap dilaksanakannya pertemuan dengan cara melihat dan mencatat fenomena-fenomena yang terjadi baik berupa kendala-kendala atau permasalahan yang ditemui selama pelaksanaan tindakan maupun hal-hal yang positif yang terjadi pada proses pembelajaran. Observasi juga digunakan untuk mendapatkan data yang berupa aktivitas siswa. Evaluasi mengenai hasil belajar siswa dilaksanakan pada akhir siklus dengan memberikan tes hasil belajar mata pelajaran IPS. Refleksi dilakukan pada akhir siklus, sebagai acuan dalam refleksi ini adalah hasil belajar siswa. Hasil refleksi ini digunakan sebagai dasar untuk memperbaiki serta menyempurnakan perencanaan dan pelaksanaan tindakan pada siklus berikutnya. Tujuan refleksi siklus I ini adalah untuk melihat kelemahan-kelemahan dan kelebihan-kelebihan yang terjadi dalam tindakan sebelumnya dan memberikan masukan pada tindakan di siklus berikutnya, sehingga kelemahan dalam siklus berikutnya dapat ditekan seminimal mungkin untuk memperoleh hasil yang optimal.

Pengumpulan data pada dasarnya merupakan suatu kegiatan operasional agar tindakannya masuk pada pengertian penelitian yang sebenarnya. Pencarian data di lapangan dengan mempergunakan alat pengumpulan data yang sudah disediakan secara tertulis ataupun dengan alat lain, yang akan dicari di lapangan. Dalam penelitian ini menggunakan metode pengumpulan data dengan tes. Tes yang digunakan adalah tes hasil belajar yang digunakan untuk mengukur pencapaian belajar setelah mempelajari materi mata pelajaran IPS yang telah diberikan. Tahapan setelah mengumpulkan data adalah analisis data. Dalam penelitian tindakan kelas ini, data yang dikumpulkan oleh peneliti akan dianalisis dengan menggunakan analisis data deskriptif yaitu dengan mencari nilai rata-rata siswa, persentase daya serap dan persentase ketuntasan belajar.

\section{Hasil dan Pembahasan}

Penerapan model pembelajaran kooperatif tipe tipe Teams Games Tournament (TGT) dalam pembelajaran IPS diperoleh hasil belajar sebagai berikut. Hasil penelitian menunjukkan bahwa terjadi peningkatan hasil penelitian dari Pra siklus-Siklus I dan Siklus II secara rinci ditunjukan pada Tabel 1.

Tabel 1. Perkembangan Hasil Belajar

\begin{tabular}{lllll}
\hline Uraian & Pra Siklus & Siklus I & Siklus II & Peningkatan \\
\hline Jumlah & 960 & 1065 & 1170 & 105 \\
Rata-rata Kelas & 60 & 67 & 73 & 6 \\
Daya Serap & $60 \%$ & $67 \%$ & $73 \%$ & $6 \%$ \\
Ketuntasan Belajar & $31 \%$ & $69 \%$ & $94 \%$ & $25 \%$ \\
\hline
\end{tabular}

Berdasarkan Tabel 1 di atas, dapat dijelaskan bahwa nilai rata-rata kelas mengalami peningkatan dari 60 pada hasil belajar prasiklus menjadi 67 pada siklus I, kemudian meningkat menjadi 73 pada siklus II. Sedangkan nilai daya serap siswa juga mengalami peningkatan dari $60 \%$ pada prasiklus meningkat menjadi $67 \%$ pada siklus I, kemudian meningkat menjadi $73 \%$ pada siklus II. Ketuntasan belajar juga mengalami peningkatan dari 31\% pada hasil belajar prasiklus, naik menjadi 69\% pada siklus I, kemudian meningkat menjadi $94 \%$ pada siklus II. Berdasarkan hasil analisis pada masing-masing siklus menunjukkan peningkatan nilai rata-rata kelas mengalami peningkatan dari 60 pada hasil belajar prasiklus menjadi 67 pada siklus I, kemudian meningkat menjadi 73 pada siklus II. Dengan demikian dapat disimpulkan bahwa melalui penerapan model pembelajaran kooperatif tipe TGT dapat meningkatkan hasil belajar IPS siswa kelas VI SD Negeri 1 Sekumpul. Hasil penelitian menunjukkan bahwa penerapan model pembelajaran kooperatif tipe TGT dapat meningkatkan hasil belajar IPS. Hasil penelitian yang menunjukkan bahwa model pembelajaran kooperatif tipe TGT dapat meningkatkan hasil 
belajar IPS disebabkan karena pembelajaran kooperatif tipe TGT yang dikembangkan memperhatikan beberapa hal berikut, seperti (1) Model TGT tidak hanya membuat peserta didik yang cerdas (berkemampuan akademis tinggi) lebih menonjol dalam pembelajaran, tetapi peserta didik yang berkemampuan akademik lebih rendah juga ikut aktif dan mempunyai peranan yang penting dalam kelompoknya, (2) Dengan model pembelajaran ini, akan menumbuhkan rasa kebersamaan dan saling menghargai sesama anggota kelompoknya, (3) Dalam model pembelajaran ini, membuat peserta didik lebih bersemangat dalam mengikuti pelajaran. Karena dalam pembelajaran ini, guru menjanjikan sebuah penghargaan pada peserta didik atau kelompok terbaik, dan (4) Dalam pembelajaran peserta didik ini membuat peserta didik menjadi lebih senang dalam mengikuti pelajaran karena ada kegiatan permainan berupa tournamen dalam model ini.

Model pembelajaran kooperatif tipe TGT sesungguhnya adalah model pembelajaran yang menyajikan suatu konsep dengan disertai belajar secara kelompok dan permainan, serta berhubungan dengan bagaimana seseorang belajar atau gaya atau cara siswa belajar, relevansi dan manfaat penuh terhadap belajar. Model pembelajaran TGT ini sangat cocok untuk diterapkan karena tahap siswa SD dimana siswa masih suka dengan dunia bermain (Listyarini et al., 2018). TGT dapat meningkatkan pemahaman konsep siswa (Laila \& Rahmat, 2018). Model pembelajaran ini dapat meningkatkan kinerja pengajaran guru dan prestasi belajar siswa, serta merupakan suatu kiat, petunjuk, strategi, dan seluruh proses belajar yang dapat mempertajam pemahaman daya ingat, serta belajar sebagai proses yang menyenangkan dan bermakna (Susanna, 2018). TGT salah satu tipe atau model pembelajaran kooperatif yang mudah diterapkan, melibatkan aktivitas seluruh siswa tanpa harus ada perbedaan status, melibatkan peran siswa sebagai tutor sebaya dan mengandung unsur permainan dan penguatan (AP \& Amir, 2018; Rosdiani et al., 2013; Teladaningsih et al., 2019). TGT diharapkan mampu membuat peserta didik lebih semangat belajar dan tidak merasa bosan, karena model pembelajaran TGT memuat adanya game/turnamen di dalam kelas yang dimana pemenang turnamen ini akan diberikan suatu penghargaan, maka peserta didik akan terpacu untuk menjadi yang terbaik (Hikmah et al., 2018). Pembelajaran TGT di kelas, menuntut siswa aktif dalam pembelajaran baik secara fisik, mental maupun emosional guna mencapai hasil belajar yang optimal(Astuti1 \& Kristin, 2017). Jadi, adanya model pembelajaran TGT akan meningkatkan hasil belajar siswa, karena proses pembelajaran yang dilakukan sesaui dengan karakteritik anak SD. Dengan memperhatikan aspek-aspek yang telah diuraikan di atas, menunjukkan bahwa penerapan model pembelajaran kooperatif tipe TGT yang dikembangkan dapat meningkatkan hasil belajar IPS. Dari paparan di atas, secara umum penelitian ini telah mampu menjawab permasalahan penelitian yang dirumuskan dalam rumusan masalah. Penerapan model pembelajaran kooperatif tipe TGT untuk meningkatkan hasil belajar IPS telah mencapai target seperti yang ditetapkan dalam indikator keberhasilan dalam penelitian ini.

Hasil penelitian ini diperkuat dengan hasil penelitian yang dilakukan oleh Syarani, (2019) menyatakan bahwa penggunaan model pembelajaran kooperatif tipe TGT (Teams Games Tournaments) terbukti efektif dengan adanya perbedaan yang signifikan antara rata-rata hasil belajar pemelajar antara kelas eksperimen dan kelas kontrol. Suaeb et al., (2018) menunjukkan bahwa hasil penelitian selama dua siklus menunjukkan bahwa penerapan pembelajaran kooperatif model Teams Games Tournament (TGT) berbantuan media tebak gambar dapat meningkatkan hasil belajar IPS siswa kelas. Hasil belajar siswa pada pra tindakan yakni dari 30 siswa hanya 17 siswa atau sebesar $56,7 \%$ siswa tuntas, setelah tindakan pada siklus I sebanyak 21 siswa tuntas atau 70,0\%, kemudian meningkat pada siklus II sebanyak 26 siswa atau $86,7 \%$ siswa tuntas. Peningkatan hasil belajar siswa pada siklus I dibandingkan hasil belajar siklus II sebesar 16,6\%. Ketuntasan belajar klasikal sebesar 86,6. Penelitian yang dilakukan oleh Puspitasari et al., (2019) model pembelajaran TGT menjadi penting untuk meningkatkan kemampuan pemecahan matematis siswa.

\section{Simpulan dan Saran}

Berdasakan rumusan masalah dan hasil penelitian, dapat ditarik simpulan bahwa penerapan model pembelajaran kooperatif tipe TGT dapat meningkatkan hasil belajar IPS pada siswa kelas VI SD. TGT salah satu tipe atau model pembelajaran kooperatif yang mudah diterapkan, melibatkan aktivitas seluruh siswa tanpa harus ada perbedaan status, melibatkan peran siswa sebagai tutor sebaya dan mengandung unsur permainan dan penguatan. 


\section{Daftar Pustaka}

Andari, I. A. K. M. L., Darsana, I. W., \& Asri, A. S. (2019). Pengaruh Model Problem Based Learning (PBL) Berbasis Portofolio Terhadap Hasil Belajar IPS. International Journal of Elementary Education, 2(2), 70. https://doi.org/10.23887/jet.v2i2.16184.

AP, N., \& Amir, A. E. K. (2018). Penerapan Model Pembelajaran Kooperatif Tipe Teams Games Tournament Untuk Meningkatkan Hasil Belajar Ips Siswa Sd Inpres 7/83 Pasempe Kabupaten Bone. JIKAP PGSD: Jurnal Ilmiah Ilmu Kependidikan, 2(2), 53. https://doi.org/10.26858/jkp.v2i2.6945.

Astuti1, W., \& Kristin, F. (2017). Penerapan Model Pembelajaran Teams Games Tournamentuntuk Meningkatkan Keaktifan Dan Hasil Belajar Ipa Pada Siswa Sekolah Dasar. Jurnal Didaktika Dwija Indria (SOLO), 5(5), 155-162. https://doi.org/http://dx.doi.org/10.23887/jisd.v1i3.10471.

Hikmah, M., Anwar, Y., \& Riyanto. (2018). Penerapan Model Pembelajaran Team Games Tournament (TGT) Terhadap Motivasi dan Hasil Belajar Peserta Didik pada Materi Dunia Hewan Kelas X di SMA Unggul Negeri 8 Palembang. Jurnal Pembelajaran Biologi, 5(1), 56-73. https://ejournal.unsri.ac.id/index.php/fpb/article/download/7049/pdf.

Horohiung, V., \& Sarkadi, M. W. (2016). Pengaruh Strategi Pembelajaran Dan Kemampuan Berpikir Logis Terhadap Hasil Belajar Sejarah Siswa Jurusan Ips Sma Negeri 2 Pematangsiantar. Jurnal Teknologi Pendidikan (JTP), 9(2), 1-10. https://doi.org/10.24114/jtp.v9i2.4900.

Kristin, F., \& Kencana, S. F. (2019). Pengaruh Kedisiplinan Belajar Terhadap Hasil Belajar Mahasiswa dalam Mata Kuliah Konsep Dasar IPS. Jurnal Pendidikan Ilmu Sosial, 28(1), 31. https://doi.org/10.17509/jpis.v28i1.17810.

Kurniasari, E. F., \& Setyaningtyas, E. W. (2017). Peningkatan Hasil Belajar IPS Melalui Penerapan Model Pembelajaran Kooperatif Tipe Think Pair and Share (TPS) dengan Teknik Gallery Walk. Journal of Education Research and Evaluation, 1(2), 120. https://doi.org/10.23887/jere.v1i2.10074.

Laila, F., \& Rahmat, A. (2018). Meningkatkan Pemahaman Konsep Siswa Melalui Teams Games Tournament (Tgt): Meta Analisis. SOSIO-DIDAKTIKA: Social Science Education Journal, 1(1), 15-23. https://doi.org/10.15408/sd.v1i1.9518.

Listyarini, D. W., As'ari, A. R., \& Furaidah. (2018). Pengaruh Model Teams Games Tournament Berbantuan Permainan Halma terhadap Minat dan Hasil Belajar pada Materi Bunyi Siswa Kelas IV Sekolah Dasar. Jurnal Pendidikan: Teori, Penelitian, Dan Pengembangan, 3(5), 538-543. https://doi.org/http://dx.doi.org/10.17977/jptpp.v3i5.10930.

Puspitasari, D., Muliawanti, S., Gunawan, \& Sairan. (2019). Analisis Kemampuan Pemecahan Masalah Matematis Siswa Menggunakan Model Pembelajaran Team Games Tournament Sma Muhammadiyah 1 Purwokerto. AKSIOMA: Jurnal Program Studi Pendidikan Matematika, 8(1), 8390. https://doi.org/10.24127/ajpm.v8i1.1731.

Rosdiani, Khairil, \& Nurmaliah, C. (2013). Penerapan Model Pembelajaran Kooperatif Tipe Team Games Tournament (Tgt) Berbasis Praktikum Terhadap Penguasaan Konsep Sistem Pencernaan Manusia Di Sma Negeri 1 Sigli. Jurnal Biologi Edukasi, 5(2), 66-71. http://jurnal.unsyiah.ac.id/JBE/article/view/1221.

Suaeb, S., Degeng, I. N. S., \& Amirudin, A. (2018). Meningkatkan Hasil Belajar IPS Siswa Kelas V melalui Penerapan Pembelajaran Kooperatif Model Teams Games Tournament ( TGT ) Berbantuan Media Tebak Gambar. Jurnal Pendidikan: Teori, Penelitian, Dan Pengembangan, 3(1), 146-154. https://doi.org/http://dx.doi.org/10.17977/jptpp.v3i1.10435.

Susanna, S. (2018). Penerapan Teams Games Tournament (Tgt) Melalui Media Kartu Domino Pada Materi Minyak Bumi Siswa Kelas Xi Man 4 Aceh Besar. Lantanida Journal, 5(2), 93. https://doi.org/10.22373/lj.v5i2.2832.

Syarani, R. N. (2019). The Effectiveness of Cooperative Learning Model Teams Games Tournaments Type in Improving Kanji Ability. Chi'e: Jurnal Pendidikan Bahasa Jepang, 7(2), 82-90. https://doi.org/https://doi.org/10.15294/chie.v7i2.34094.

Teladaningsih, O., Mawardi, M., \& Huliana, I. (2019). Implementasi Model Pembelajaran Teams Games Tournament Meningkatkan Keterampilan Kolaboratif Peserta Didik Kelas 4 Sd. Pendas: Jurnal Ilmiah Pendidikan Dasar, IV. https://doi.org/10.23969/jp.v4i1.1530. 